\title{
STUDI EKSPLORASI BIAS ORIENTATION DAN COGNITIVE KNOWLEDGE DALAM SUKSESI USAHA RM. SIMPANG RAYA PADANG
}

\author{
Aufa Rahmatika \\ Program Magister Manajemen, Fakultas Ekonomi, Universitas Andalas, Indonesia \\ rahmatikaufa@gmail.com \\ Hafiz Rahman \\ Program Magister Manajemen, Fakultas Ekonomi, Universitas Andalas, Indonesia \\ hafizrahman@eb.unand.ac.id
}

\begin{abstract}
ABSTRAK
Beragamnya bisnis yang ada termasuk salah satunya usaha keluarga membuat usaha tersebut harus menentukan strategi untuk dapat bertahan. Diantara strategi yang dilakukan adalah mengupayakan agar suksesi dapat berjalan dari generasi pertama ke generasi berikutnya. Suksesi bisnis dilakukan bertujuan untuk mengatur kembali tata kelola bisnis agar dapat mencapai keadaan seimbang. Tujuan penelitian ini adalah untuk menganalisis perbedaan orientasi dan pengetahuan kognitif pendiri dan penerus dalam pengelolaan suksesi bisnis Rumah Makan Simpang Penelitian ini menggunakan metode kualitatif deskriptif dengan teknik pengolahan data content analysis. Hasil penelitian menunjukkan bahwa suksesi yang dijalankan awalnya berjalan dengan baik, namun dalam beberapa tahun belakangan adanya hambatan terkait perbedaan bias orientasi dan pengetahuan kognitif antara pendiri dan penerus saat ini. Perbedaan orientasi tujuan dan pengetahuan yang dimiliki seputar usaha rumah makan antara kedua pengelola ini jauh berbeda. Sehingga penerus saat ini menjadi gamang dan perlu belajar banyak hal terkait seluk beluk dan pengelolaan internal dan eksternal rumah makan.
\end{abstract}

Kata kunci:

Bias Orientasi, Pengetahuan Kognitif, Suksesi, Suksesor, Usaha Keluarga

\begin{abstract}
The variety of businesses that exist, including family businesses, makes these businesses have to determine strategies to be able to survive. Among the strategies that must be done is to strive for succession to run from the first generation to the next generation. Business succession is carried out aiming to reorganize business governance so as to achieve a balanced state. The purpose of this study was to analyze the orientation and cognitive knowledge of founders and successors in managing business succession at Simpang Restaurant. This study uses descriptive qualitative methods with data analysis data processing techniques. The results show that the succession that was carried out initially went well, but in recent years there have been obstacles related to differences in orientation and cognitive knowledge between current founders and successors. The difference in purpose and knowledge orientation about the restaurant business between the two managers is very different. So that the current successor is uncertain and needs to learn many things related to the ins and outs and internal and external management of the restaurant.
\end{abstract}

Keywords:

Bias Orientation, Cognitive Knowledge, Succession, Successor, Family Business 


\section{PENDAHULUAN}

Segala jenis usaha tentunya akan selalu berkaitan dengan upaya untuk dapat bertahan dan mampu bersaing dengan kompetitornya, salah satunya usaha keluarga. Ketersedian akan sumber daya termasuk salah satu hal yang harus diperhatikan apalagi menyangkut tata kelola bisnis dan siapa yang harus menjadi pendiri dan mengambil kepemilikan perusahaan (Shu, 2013). Pengaturan kembali terhadap tata kelola bisnis yang bertujuan untuk dapat mencapai keadaan seimbang dikenal dengan suksesi bisnis. Bagian utama dari penelitian bisnis keluarga didedikasikan untuk mengeksplorasi masalah, tantangan dan solusi yang terkait dengan suksesi usaha keluarga.

Keberhasilan sebuah perusahaan agar dapat bertahan tidak lepas dari perencanaan yang baik ketika perusahaan tersebut mendapatkan pemimpin dengan kualitas dan kapabilitas yang baik pula. Kepemimpinan yang baik akan bisa menyesuaikan kondisi terkait permasalahan yang ada pada perusahaan. Perencanaan suksesi tersebut dimulai dari proses mempersiapkan suksesor dan bagaimana perusahaan tersebut memulai persiapan suksesi dengan strategi yang telah direncanakan. Sehingga proses suksesi ini membutuhkan waktu yang cukup lama dan persiapan yang matang bagi suksesor agar ia dapat berperan langsung pada perusahaan.

Bagi calon penerus keterlibatan dalam melanjutkan usaha itu tidak lepas dari kemampuan yang didasarkan pada pengembangan dan pertukaran informasi terhadap sumber daya yang berada di perusahaan tersebut. Selain itu hal yang harus diperhatikan juga adalah orientasi, dasar berpikir, rencana dan tujuan akhir yang diharapkan oleh pemilik usaha dalam menjalankan bisnisnya, serta sejauh mana pengetahuannya agar nantinya harapan yang diinginkan oleh pemilik usaha bisa sejalan dengan para penerus usaha kedepannya (Kusuma, 2014). Dalam dunia usaha saat ini, pengetahuan dianggap sebagai sumber daya vital dalam merumuskan strategi kompetitif sebagai penerntu keberhasilan kinerja perusahaan (Islam et al, 2015). Proses transfer pengetahuan diperlukan pada perusahaan keluarga guna mempersiapkan penerus menjadi seorang pemimpin perusahaan, dengan demikian perusahaan nantinya akan berjalan secara sistematis (Kusuma, 2014). 
Tantangan tersebut tentunya mempunyai beban tersendiri oleh para penerus sebuah usaha, seperti halnya usaha Rumah Makan Simpang Raya (RM Simpang Raya). RM Simpang Raya merupakan salah satu Rumah Makan Minang yang berdiri sejak tahun 1960, dirintis oleh Bapak Muhammad Noor Datukmaharajo (alm.) bersama empat orang rekan lainnya (Martaliza, 2019). Pada awalnya Rumah Makan ini berdiri di Kota Bukittinggi-Sumatera Barat, setelah \pm 14 tahun berdiri, pada tahun 1974 berdirilah cabang baru RM Simpang Raya di pulau Jawa tepatnya di Cipanas kabupaten Cianjur dan pada tahun 1981 berdirilah RM. Simpang Raya Padang dan beberapa cabang lainnya area Sumatera, yang dipelopori oleh $\mathrm{H}$. Muswar bersama rekan lainnya.

Berkembangnya bisnis Rumah Makan ini tidak lepas dari dorongan kuat oleh pemilik usaha serta orientasi dan tujuan akhir yang diharapkan. Keberhasilan pemilik mendirikan beberapa cabang di luar kota pada saat itu adalah karena beliau melihat bisnis Rumah Makan untuk jangka panjang memiliki propsek yang baik dan tersedianya tempat yang cocok untuk buka usaha, sehingga pemilik dan rekan-rekan memberanikan diri untuk buka cabang di berbagai kota.

Setelah meninggalnya pendiri awal RM Simpang Raya Padang, maka disepakati oleh pihak keluarga untuk menyerahkan pengelolaan RM Simpang Raya Padang itu, sementara waktu kepada pengelola RM Simpang Raya Bukittinggi. Pengalihan sementara waktu ini disebabkan karena istri dari pendiri usaha RM Simpang Raya tidak mengetahui sama sekali tentang seluk-beluk usaha, sementara anak-anak pendiri pada saat itu juga masih kecil dan kemudian pendiri juga memfokuskan anak-anak pada pendidikan. Pengelolaan sementara waktu dialihkan ke pengelola RM Simpang Raya Bukittinggi sampai anak-anak pendiri suatu saat siap untuk menerima kembali tongkat suksesi, tongkat estafet kepemimpinan kepemilikan usaha Rumah Makan tersebut. Hingga akhirnya pada pergantian akhir tahun 2016 kepemilikan RM Simpang Raya diserahkan kepada salah satu anak dari pendiri usaha tersebut.

Perlahan usaha Rumah Makan mengalami kemunduran, dikarenakan pemahaman penerus yang tidak cukup menguasai orientasi usaha dan pengetahuan tentang Rumah Makan, yang mengakibatkan 
Studi Eksplorasi Bias Orientation dan Cognitive .... (Aufa Rahmatika \& Hafiz Rahman)

penerus tidak dapat mengelola usaha ini dengan baik. Sehingga diperlukannya suksesi usaha keluarga sebagai proses transisi manajemen yang membutuhkan perencanan untuk kelangsungan bisnis pada generasi penerus selanjutnya.

Analisis perbedaan orientasi pendiri dan penerus, serta perbedaan pengetahuan kognitif pendiri dan penerus dalam pengelolaan suksesi usaha Rumah Makan Simpang Raya Padang inilah yang dijadikan sebagai tujuan penelitian. Sementara itu rumusan masalah pada penelitian ini adalah bagaimana dan apa saja hal yang mendasari terjadinya perbedaan orientasi pendiri dan penerus serta bagaimana tingkat perbedaan pengetahuan kognitif pendiri dan penerus dalam pengelolaan suksesi bisnis usaha RM. Simpang Raya Padang.

Hal ini lebih lanjut digunakan sebagai dasar bagi pelaksanaan penelitian ini, yang diberi judul "Studi Eksplorasi Bias Orientation dan Cognitive Knowledge dalam Suksesi Usaha Keluarga di Rumah Makan Simpang Raya Padang"

\section{$\begin{array}{lll}\text { TINJAUANN TEORI } & \text { DAN }\end{array}$ PENGEMBANGAN HIPOTESIS}

\section{Usaha Keluarga}

$$
\text { Usaha keluarga/family business }
$$

merupakan usaha yang dimiliki dan/atau dikelola oleh sejumlah orang yang memiliki hubungan kekeluargaan, baik suami istri maupun keturunannya, termasuk hubungan persaudaraan (Woodfield et al, 2017). Menurut Alleyne et al (2015) usaha keluarga didefinisikan sebagai sebuah perusahaan dimana anggota keluarga yang memiliki hubungan darah maupun pasangan suami istri secara signifikan dapat mempengaruhi atau mengendalikan operasi bisnis.

Pada usaha keluarga, keberhasilan bisnis sebagian besar tergantung pada keluarga terkait, cara keluarga mengatur dirinya sendiri dan hubungannnya dengan bisnis. Oleh karena itu usaha keluarga yang sukses akan sering melakukan tata kelola keluarga. Tata kelola keluarga bertujuan untuk memperkuat keluarga, mengembangkan usaha bersama dengan harapan dan rencana usaha untuk masa depan. Selain itu dalam praktiknya, bisnis keluarga dan kewirausahaan saling terhubung dimana pengusaha mempunyai pengetahuan yang langsung berasal dari keluarganya, dengan demikian aktivitas kewirausahaan dapat terjadi (Suess-Reyes, 2017). 
Usaha keluarga memiliki keuntungan khusus dibandingkan dengan usaha nonkeluarga. Hal ini berkaitan dengan lebih mudahnya perusahaan keluarga menemukan peluang baru dan kombinasi lainnya seperti orientasi jangka panjang, pergantian staf, peergantian pemimpin, dan keluarga yang mengarah pada keuntungan ini (Patel \& Fiet, 2011). Selain itu, dalam usaha keluarga, anggota keluarga merupakan sumber daya yang berharga dalam perusahaan, dilihat dari segi keuangan, sosial, keinginan membawa sumber daya terbaik untuk perusahaan. Secara tidak langsung anggota keluarga yang ikut berkecimpung dalam suatu usaha keluarganya akan memberikan dukungan penuh agar kinerja perusahaanya bekerja dengan baik (Arthadian et al, 2014).

\section{Suksesi dalam Usaha Keluarga}

Suatu organisasi dikatakan sebagai usaha keluarga jika dalam generasinya tersebut membawa pengaruh kebijakan dalam usaha tersebut. Pengaruh kebijakan itu berkaitan pada suksesi dalam usaha keluarga. Suksesi pada perusahaan keluarga diartikan sebagai penyerahan tongkat kepemimpinan dari pemilik/pendiri atau pengelola kepada seorang suksesor, yang mana suksesor tersebut dapat berasal dari anggota keluarga atau pengelola profesional yang bukan dari anggota keluarga (Lesal, 2015). Sedangkan menurut Tangradi (2016) suksesi adalah proses transisi manajemen dan kepemilikan bisnis yang membutuhkan perencanaan guna memastikan kelangsungan usaha pada generasi selanjutnya.

Suksesi adalah proses yang sangat kompleks karena banyaknya keputusan sulit yang dibuat untuk memastikan bisnis bertahan dari generasi ke generasi (Short et al, 2016). Sedangkan menurut Shu (2013) suksesi merupakan salah satu pilihan untuk berkembang atau tidaknya perusahaan keluarga itu. Regenerasi perlu dilakukan agar kedepannya tidak menimbulkan sikap iri hati dan perpecahan antar anggota keluarga.

Suksesi akan menjadi penting jika terdapatnya upaya keberlangsungan dalam mempertahankan usaha tersebut, keberlangsungan itu dapat dilakukan dengan perencanaan suksesi. Menurut Susanto \& Susanto (2013) perencanaan suksesi akan membantu perusahaan dalam menjaga stabilitas dan kinerja serta menjaga keharmonisan keluarga. Sedangkan menurut Budiman \& Mustamu (2014) perencanaan 
suksesi itu terjadi berdasarkan tiga hal, yaitu:

pertama faktor penentu perencanaan suksesi

yang berisi tentang tingkat kesiapan suksesor,

perencanaan dan pengendalian persepsi diri,

serta hubungan antara keluarga dengan

anggota bisnis. Kedua pemilihan suksesor

yang terdiri dari nilai komunikatif dan nilai

objektif. Ketiga proses mentoring yang

merupakan poses pelatihan dan pengembangan

knowledge dan skill, strategi dan visi, kepemimpinan, dan evaluasi kinerja. Sehingga untuk meminimalisir masalah yang akan timbul dikemudian hari maka perlu disiapkan perencanaan suksesi secara matang.

\section{Bias Orientasi dalam Usaha Keluarga}

\section{Orientasi \\ Kewirausahaan}

(Entrepreneurial Orientation) atau yang disingkat dengan EO merupakan konsep yang dimiliki perusahaan terkait sikap dan perilaku yang umumnya bersifat strategis, berhubungan dengan kegiatan operasional dan digunakan untuk merevitalisasi perusahaan itu sendiri (Shu et al., 2019). Sedangkan menurut Wales (2016) EO didefinisikan sebagai strategi perusahaan secara keseluruhan, praktik pengambilan keputusan, inovatif dan proaktif. Pengambilan keputusan dilihat dari sejauh mana perusahaan cenderung mengambil keputusan terkait usaha yang dijalaninya. Inovatif dilihat dari sejauh mana perusahaan menyukai perubahan dan bergantung pada perbedaan inovasi baik dari segi teknologi, manajerial, produk) yang mana perbedaan itu bertujuan untuk mendapatkan keunggulan kompetitif. Proaktif mencerminkan sejauh mana perusahaan tersebut mampu bersaing di pasar baru.

Perusahaan yang berorientasi kewirausahaan juga akan menyediakan sumber daya dan akan mengubah struktur yang diperlukan untuk melakukan pembaruan strategis (Kuratko, 2010). Orientasi kewirausahaan yang inovatif dan proaktif akan membantu perusahaan membuka pengetahuan lebih luas lagi, kemudian dimensi pengambilan resiko dari orientasi kewirausahaan juga akan menciptakan budaya organisasi yang toleran. Sehingga jika dikaitkan dengan konteks pelatihan kewirausahaan dan pengembangan diri, orientasi kewirausahaan ini tidak hanya mempengaruhi pengembangan kompetensi individu tetapi juga mempengaruhi sifat ide bisnis baru yang akan dikembangkan individu atau kelompok tertentu (Elenurm, 2012) 
Dengan demikian baik orientasi

kewirausahaan maupun pembaruan strategis perusahaan itu akhirnya dapat meningkatkan kinerja perusahaan (Bierwerth et al, 2015).

\section{Pengetahuan dalam Usaha Keluarga}

Pengetahuan memiliki konteks dan diciptakan dengan mengintegrasikan informasi dengan pengalaman, intuisi dan penilaian (Warnar, 2012). Karakteristik sumber daya manusia dianggap membantu dalam menciptakan keunggulan kompetitif, terlihat dari keterampilan, pengalaman dan pengetahuan (Akhavan et al, 2013). Hal tersebut diperkuat oleh penyataan Khvatova et al (2016) yang menyatakan bahwa pengetahuan merupakan sumber daya utama untuk melakukan inovasi dan keunggulan kompetitif, yang mana guna mewujudkan hal tersebut dibutuhkan peran individu maupun kelompok agar ikut terlibat. Selain itu ia juga mengungkapkan bahwa pengetahuan dianggap sebagai sumber daya paling penting dalam strategi organisasi. Keunggulan kompetitif perusahaan ini dinilai berdasarkan kemampuan perusahaan mengeksploitasi pengetahuan yang ada (stok pengetahuan) dan mengeksplorasi pengatahuan baru (arus pengetahuan) (Lin,
2015)

$$
\text { Menurut Vij \& Farooq }
$$
menyatakan bahwa transfer pengetahuan dianggap sebagai langkah vital menuju manajemen pengetahuan yang sukses. Sehingga menurut alurnya proses transfer pengetahuan ini diberikan oleh pendahulu terhadap penerus secara bertahap dan dengan langkah-langkah yang tepat agar penerus dapat menyerap dan mengimplementasikan pengetahuan tersebut dalam perusahaan (Prasetio \& Nugraheni, 2018). Transfer pengetahuan tersebut dapat dilakukan oleh perusahaan dengan mentransfer kepemimpinan kepada satu atau beberapa anggota keluarga (Warnar, 2012). Selama proses transfer pengetahuan, penerus dapat melakukan metode pembelajaran dengan mendapatkan pengalaman secara kongkrit dan melakukan eksperimen serta belajar dengan cara learning by doing sehingga penerus dapat menyelesaikan masalah (kasus demi kasus) (Kusuma, 2016). 


\section{Kerangka Penelitian}

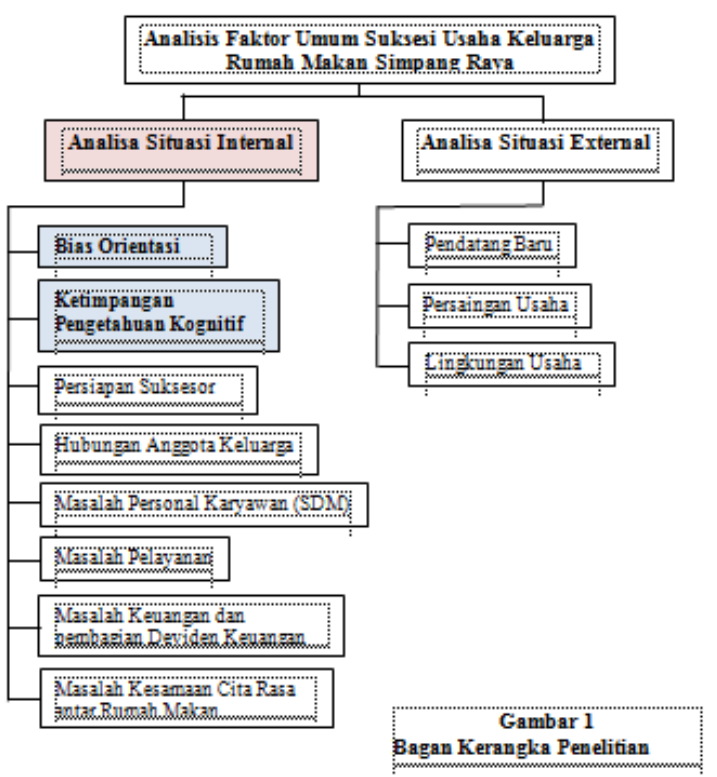

Gambar 1. Bagan Kerangka Penelitian

\section{Proposisi Penelitian}

Proposisi adalah dugaan sementara dari sebuah penelitian terhadap fenomena yang terjadi. Berdasarkan kerangka penelitian, maka proposisi penelitian adalah: "Bias orientasi dan ketimpangan cognitive knowledge antara pendiri dan penerus usaha keluarga merupakan bagian dari faktor-faktor yang dapat menentukan sukses atau gagalnya proses suksesi dalam sebuah usaha keluarga"

\section{METODE RISET}

Penelitian ini menggunakan pendekatan kualitatif melalui metode fenomologi dan menggunakan metode pengumpulan data melalui wawancara. Menurut (Cresswell,
2013) metode fenomologi menggambarkan arti sebuah pengalaman hidup untuk beberapa orang tentang sebuah konsep atau fenomena. Bentuk pertanyaan wawancara yang dilakukan pada penelitian ini berupa wawancara terbuka (open interview). Peneliti kemudian mencerna informasi yang didapatkan dari hasil wawancara tersebut, guna menganalisis Bias Orientation dan Cognitive Knowledge Pada Suksesi Usaha Keluarga RM. Simpang Raya Padang.

Pada penelitian ini sumber data yang digunakan hanya sumber data primer dengan unit analisis atau informan yang digunakan pada penelitian ini adalah sebanyak 7 orang, yakni istri pendiri, 1 orang rekan pendiri usaha, 2 orang penerus/pengelola, 1 orang karyawan, 1 orang suppilier dan 1 orang konsumen RM. Simpang Raya Padang.

Informan tersebut dipilih guna memenuhi kebutuhan peneliti pada penelitian ini, seperti untuk informan pendiri, dikarenakan pendiri utama RM. Simpang Raya Padang telah meninggal dunia maka peneliti memutuskan untuk mewawancara istri pendiri dan rekan pendiri sesama mendirikan usaha rumah makan (awalnya RM. Simpang Raya 
Cipanas). Selanjutnya untuk informan penerus, peneliti memutuskan untuk mewawancara pengelola RM. Simpang Raya Bukittinggi dan Pengelola RM. Simpang Raya saat ini (yang merupakan salah satu anak dari pendiri utama). Kemudian peneliti juga membutuhkan informan seperti karyawan, supplier dan konsumen RM. Simpang Raya Padang. Data dari informan tersebut dibutuhkan peneliti guna untuk mengkonfirmasi/memperkuat pernyataan, atas uraian yang diberikan oleh informan sebelumnya.

Jenis wawancara yang akan dilakukan adalah semi-terstruktur. Wawancara semiterstruktur merupakan jenis wawancara yang termasuk ke dalam kategori in-dept interview, dimana dalam pelaksanaannya permasalahan akan ditemukan secara terbuka, informan yang akan diwawancara akan diminta pendapat dan ide-idenya.

Data yang telah diperoleh akan dianalisis dengan menggunakan Content Analisis (Analisis Isi). Analisis isi adalah satu pendekatan dan metode dalam penelitian kualitatif yang menjadikan teks (tulisan maupun wacana) sebagai objek kajian atau satuan yang dianalisis (Ibrahim, 2015). Dalam penelitian kualitatif, analisis isi ditekankan pada bagaimana peneliti melihat isi komunikasi secara kualitatif, pada bagaimana peneliti memaknai isi komunikasi, membaca simbol-simbol, memaknakan isi interaksi simbolik yang terjadi pada komunikasi (Burhan, 2013).

Berikut langkah-langkah dalam penggunaan Content Analysis, diantaranya (Burhan, 2013):

1. Peneliti harus menemukan fenomena komunikasi yang ingin diamati, diteliti berdasarkan tujuan penelitian;

2. Menentukan unit analisis dan objek penelitian yang dijadiksn sebagai sasaran penelitian. Kalau objek penelitian berhubungan dengan pesan-pesan, maka lakukan identifikasi terhadap pesan dan media yang mengantarkan pesan itu;

3. Memberikan coding terhadap istilahistilah atau penggunaan kata dan kalimat yang relevan, yang paling banyak muncul dalam media komunikasi. Saat pemberian coding catat konteks mana istilah itu muncul;

4. Lakukan klasifikasi terhadap coding 
Studi Eksplorasi Bias Orientation dan Cognitive .... (Aufa Rahmatika \& Hafiz Rahman)

yang telah dilakukan. Hal ini berguna

untuk melihat sejauh mana satuan makna

berhubungan dengan tujuan penelitian

dan klasifikasi ini dimaksudkan untuk

membangun kategori dari setiap

klasifikasi;

5. Satuan makna dan kategori tersebut dianalisis dan dicari hubungan satu dengan lainnya untuk menemukan makna, arti dan tujuan isi komunikasi;

6. Hasil analisis dideskripsikan dalam bentuk draft laporan peneltian

\section{HASIL PENELITIAN DAN}

\section{PEMBAHASAN}

\section{Bias Orientasi}

Proses Terjadinya Perbedaan Orientasi

Pendiri dan penerus Dalam Pengelolaan

\section{Suksesi Usaha Keluarga}

\section{a. Tujuan mendirikan dan menjalankan usaha rumah makan}

Berdasarkan temuan hasil wawancara yang didapatkan bahwa diantara dua pendiri ini memiliki tujuan yang sama yaitu ingin berkembang. Namun terdapat sedikit perbedaan yakni pendiri yang satu karena telah memiliki usaha rumah makan sebelumnya ia cenderung ingin melakukan pengembangan usaha, kemudian pendiri yang satu lagi lantaran sebelumnya hanya menjadi karyawan orang, maka ia ingin berkembang juga dengan membuka usaha rumah makan.

Sementara itu tujuan pengelola menjalankan usaha rumah makan adalah samasama ingin meneruskan, mempertahankan, mamajukan usaha yang telah susah payah dibangun oleh orang tuanya.

\section{b. Cara pendiri / penerus memasarkan} usaha rumah makan

Ketika usaha RM. Simpang Raya baru buka, pendiri mencoba memasarkan usaha tersebut dengan cara menjemput bola, maksudnya dengan mengundang para pejabat, kerabat maupun relasi untuk makan ke di RM. Simpang Raya. Namun terdapat hal yang harus diperhatikan adalah utamakan selalu rasa masakan, pelayanan dan kebersihan. Karena jika nanti orang sudah mengetahui tempat, maka orang akan mempromosikannya dari mulut ke mulut.

Namun belakangan ini yang sangat disayangkan, setelah pendiri RM. Simpang Raya Padang meninggal dunia, memang terjadi nya penurunan pada rumah makan ini 
secara keseluruhan. Sehingga pengelola saat ini berupaya untuk melakukan pembenahan dan mencoba bangkit kembali seperti dulu.

\section{c. Inovasi}

Secara umum, inovasi yang dilakukan pada RM. Simpang Raya adalah dengan menambah varian pada menu makanan dan minuman. Tujuannya agar konsumen tidak merasa bosan dengan masakan yang disajikan. Selain itu terdapat pula pembaharuan dari segi bangunan dari rumah makan itu sendiri (renovasi).

\section{d. Sistem Pengelolaan}

Setelah meninggalnya pendiri RM. Simpang Raya Padang, dahulunya pengalihan kekuasaan sementara itu jatuh kepada pengelola RM. Simpang Raya Bukittinggi. Namun saat ini, setelah anak dari pendiri tersebut sudah dewasa dan dirasa telah mampu untuk mengelola usaha, maka terjadi pemindahan kekuasaan kepada salah satu anak dari pendiri tersebut. Namun secara umum pengontrolan juga masih melibatkan pengelola sebelumnya.

Sementara itu, pengelola saat ini di samping menjadi pengelola rumah makan, ia juga mempunyai pekerjaan tetap di tempat lain. Sehingga bisa dikatakan pengelola tersebut harus banyak belajar untuk bisa samasama menjalankan tugas dan amanah yang ada. Untuk memaksimalkan pengontrolan di rumah makan, maka pengelola menunjuk orang kepercayaan untuk memantau keadaan di lapangan, termasuk masalah keuangan, operasional, SDM dan lain-lain.

\section{e. Hubungan dengan Pengelola}

Pada bagian ini peneliti mengambil ulasan dari sudut pandang dari karyawan dan supplier. Ini perlu dilakukan guna menggambarkan situasi yang sudah atau sedang terjadi. Berdasarkan hasil wawancara dengan karyawan, karyawan mengaku memiliki hubungan baik dengan pengelola. Hanya saja, karena pengelola tidak selalu standby di rumah makan sehingga terkadang karyawan mengharapkan pendekatan yang lebih dengan pengelola, demi kemajuan rumah makan kedepan. Kemudian dari sudut pandang supplier, ia mengaku bahwa selama menjadi supplier di RM. Simpang Raya Padang hubungan yang terjalin berjalan dengan baik dan secara kekeluargaan. Ia juga mengaku tidak pernah memiliki masalah baik dengan pengelola maupun dengan karyawan rumah 
Studi Eksplorasi Bias Orientation dan Cognitive .... (Aufa Rahmatika \& Hafiz Rahman)

makan tersebut

\section{f. Harapan Terhadap Keberlangsungan}

\section{Usaha}

Pada bagian ini peneliti mengambil ulasan dari sudut pandang karyawan dan konsumen. Tujuan peneliti disini adalah pengelola nantinya mampu mendengar dan mewujudkan harapan tersebut. Menurut penjelasan karyawan, terdapat harapan agar RM. Simpang Raya Padang kedepannya melakukan pembenahan, pengarahan dan pelatihan kepada SDM. Sementara itu dari sudut pandang konsumen ia mengharapkan agar RM. Simpang Raya Padang dapat mengembalikan cita rasa masakan yang dulu menjadi masakan favorit dari masyarakat kota padang, kemudian promosi supaya lebih digencarkan.

Secara keseluruhan, terjadinya bias pada orientasi kewirausahaan. Hal ini terjadi karena beberapa faktor, namun intinya dikarenakan suksesi pada usaha rumah makan ini tidak berjalan dengan baik, sehingga menyebabkan yang seharusnya orientasi dapat berjalan dengan lancar, tapi yang terjadi tidak sesuai dengan harapan. Berdasarkan penelitian yang dilakukan oleh Cong et al (2017), dalam konteks orientasi kewirausahaan seharusnya dapat memotivasi para pemangku usaha untuk memberikan yang terbaik dan mendukung perusahaannya.

Faktor-faktor yang mendasari terjadinya perbedaan orientasi pendiri dan penerus dalam pengelolaan Suksesi Usaha Keluarga

a. Faktor internal yang mempengaruhi suksesi usaha RM. Simpang Raya Padang

Menurut para informan, semuanya berpendapat sama bahwa faktor internal yang mempengaruhi usaha RM. Simpang Raya adalah faktor kebersihan, pelayanan, rasa masakan, serta hubungan antara karyawan dengan pengelola. Namun salah satu informan menyatakan diantara faktor-faktor diatas, faktor yang berhubungan dengan karyawanlah yang sangat berpengaruh, karena ia memiliki kaitan dengan keberlangsungan usaha.

\section{Cognitive Knowledge}

Tingkat Perbedaan Pengetahuan Kognitif Pendiri dan Penerus dalam Pengelolaan Suksesi Usaha Keluarga

1. Informasi membuka / menjalankan Usaha Rumah Makan

Berdasarkan temuan hasil wawancara 
dengan para pendiri, semuanya sepakat menyatakan pendapat yang sama, bahwa dulunya mereka membuka usaha karena mempunyai link untuk bisa bergabung di RM. Simpang Raya. Sehingga rumah makan tersebut dibuka di beberapa tempat. Namun untuk membuka usaha rumah makan tentu juga perlu didasari oleh pengalaman. Pendiri mengaku bahwa mereka ada yang telah mempunyai usaha rumah makan sebelumnya dan ada juga yang telah menjadi karyawan di rumah makan milik keluarganya.

Sementara itu, berdasarkan hasil wawancara dengan para pengelola mereka mangaku bahwa pengetahuan dan informasi terkait rumah makan itu diperolehnya sejak dulu ia ikut membantu orang tua ketika bekerja, serta pengelola lainnya mengaku memperoleh ilmu seputar rumah makan setelah mendapatkan arahan dan melakukan diskusi dengan pengelola sebelumnya.

\section{Cara Pendiri dan Penerus mengambil Keputusan}

Berdasarkan hasil wawancara dengan semua informan, rata-rata jawaban yang di ungkapkan hampir sama yaitu di cari solusi terbaik untuk menyelesaikan masalah yang dihadapi. Perbedaan yang terjadi hanya dari teknis menyelesaikan masalah atau siapa orang yang terjun terlebih dahulu untuk menyelesaikan masalah tersebut. Menurut salah satu pendiri, ia mengungkapkan bahwa persoalan yang terjadi itu sebaiknya diselesaikan terlebih dahulu oleh pihak managemen rumah makan (manajer operasional/ keuangan/ SDM), kemudian jika masalah itu belum juga terselesaikan, saatnya pendiri ikut berpartisipasi dalam menyelesaikan masalah yang terjadi.

\section{Berbagi Pengalaman}

Berdasarkan hasil wawancara dengan informan, membagikan pengalaman ini ditunjukkan dengan cara yang berbeda. Masing-masing pendiri pun juga memiliki pengalaman yang berbeda dalam membagikan ilmunya kepada penerusnya.

Setelah dilakukannya wawancara dengan istri pendiri, sepengetahuan beliau dahulu lantaran anak mereka masih kecil, maka transfer ilmu tidak sempat diberikan kepada anak, namun kepada karyawan yang ia percaya dan di rasa dapat memegang amanah yang diberikan. Transfer ilmu diberikan dengan cara membagikan pengalaman seputar 
rumah makan, ikut terjun dalam kegiatan rumah makan, diajarkan segala hal tentang rumah makan baik dari segi operasional, mengelola keuangan maupun mengelola karyawan (SDM), serta bagaimana cara mengontrol dan memberikan cara evaluasi kepada karyawan. Pernyataan tersebut diperkuat oleh Kusuma (2016) yang menyatakan bahwa untuk mentransfer pengetahuannya, pendahulu melakukannya secara lisan dalam bentuk cerita maupun arahan kepada penerus. Selain dilakukan secara lisan, pendahulu juga mengkombinasikan metode transfer dengan pemberian contoh.

Sementara informan yang merupakan rekan pendiri, sesama membuka RM Simpang Raya Cipana mengaku bahwa pada mulanya ia merasa tidak perlu membagikan pengetahuan kepada penerusnya seputar rumah makan, karena awalnya ia merasa bahwa anaknya harus mempunyai pekerjaan yang lebih baik dari yang dia miliki sekarang (selain rumah makan), sehingga disana tidak ada proses transfer ilmu kepada penerus.

Namun, hal yang terjadi adalah meskipun pendiri yang bersangkutan tidak ingin anaknya berusaha di rumah makan, ternyata kemauan dari si anak (penerus) yang ingin ikut berkecimpung membantu sang Ayah dan berusaha mengembangkan usaha rumah makan yang ada. Pernyataan ini dibuktikan dengan berkembangnya RM. Simpang Raya di wilayah jawa dan sekitarnya. Ditambah lagi dengan penerus yang telah mempunyai bekal pendidikan di bangku perkuliahan seputar bisnis dan manajemen, sehingga menjadi penunjang penerus untuk melanjutkan usaha orangtuanya.

Pernyataan diatas erat kaitannya dengan penelitian (Chirico, 2008), yang menyatakan bahwa Learning by doing menjadi sangat penting dari pada hanya melakukan pembelajaran di bangku kuliah. Cara belajar yang langsung terjun ke lapangan dengan memahami bagaimana jalannya usaha keluarga, menjadikannya mampu bertahan hingga ke generasi-generasi yang akan datang.

\section{KESIMPULAN, IMPLIKASI DAN \\ KETERBATASAN}

Rumah Makan Simpang Raya Padang pernah menjadi salah satu rumah makan padang terfavorit bagi masyarakat kota Padang pada zamannya. Namun dalam beberapa tahun belakangan ini, disebabkan oleh beberapa 
faktor, termasuk banyaknya persaingan dari usaha yang sejenis ternyata mempengaruhi berjalannya usaha rumah makan tersebut. Salah satu faktor internal yang mempengaruhi adalah suksesi usaha keluarga.

Awalnya suksesi usaha RM. Simpang Raya ini telah berhasil dijalankan, dengan adanya penyerahan tongkat kepemimpinan dari pendiri kepada pengelola (non-keluarga) yang ia percayai dapat melanjutkan usaha keluarga ini. Keberhasilan suksesi berlangsung cukup lama. Hingga akhirnya di karenakan faktor dan beberapa hal yang mempengaruhi keberlangsungan usaha ini, suksesor yang diberikan amanah untuk menjalankan usaha tadi memutuskan untuk menyerahkan kembali tongkat estafet kepemimpinan kepada suksesor lainnya yaitu salah seorang anak pendiri rumah makan tersebut.

Setelah dijalankannya usaha rumah makan oleh suksesor tersebut, ternyata ia mengalami hambatan. Salah satu penyebab terjadinya hambatan tersebut karena adanya perbedaan bias orientation dan cognitive knowledge antara pendiri ataupun suksesor sebelumnya dengan suksesor yang menjalankan usaha keluarga RM. Simpang Raya pada saat ini, dan di iringi oleh faktor lainnya seperti suksesor saat ini belum bisa fokus pada satu bidang usaha yakni nya rumah makan.

Orientasi tujuan yang diharapkan oleh suksesor sebelumnya adalah untuk meneruskan amanah orang tua nya, yakni adanya rumah makan itu sebagai wadah usaha untuk menampung tenaga kerja yang samasama ingin berusaha rumah makan. Sementara itu suksesor saat ini, orientasi tujuannya dalam meneruskan usaha RM. Simpang Raya adalah untuk mempertahankan rumah makan agar tetap ada dan eksis di kota Padang, serta mengusahakan agar karyawan tetap bertahan. Perbedaan orientasi tujuan dan pengetahuan yang dimiliki seputar usaha rumah makan antara kedua pengelola ini jauh berbeda. Hal ini disebabkan juga oleh pengaruh meninggalnya pendiri usaha (ayah suksesor), sehingga tidak sampainya amanah tersebut kepada dirinya. Penyebab itulah yang membuat suksesor saat ini perlu belajar banyak hal terkait seluk beluk dan pengelolaan rumah makan yang semestinya, Implikasi penelitian ini memberikan pemahaman bahwa suksesi usaha keluarga pada RM. Simpang Raya Padang dijadikan sebagai objek dalam penelitian ini. 
Berdasarkan hasil penelitian, disimpulkan bahwa pengelola saat ini / suksesor dinilai memiliki perbedaan orientasi dan pengetahuan dengan pendiri terdahulu dalam melanjutkan dan mengelola usaha RM. Simpang Raya Padang. Hal tersebut dapat dilihat pada uraian berikut:

1. Pola usaha keluarga yang dapat dilakukan antara pemilik-pengelola-suksesor usaha RM. Simpang Raya Padang adalah sebagai berikut:

a. Terkait dengan upaya meminimalisir perbedaan orientasi usaha, hal yang dapat dilakukan adalah dengan melakukan sosialisasi/sharing orientasi antara pendiri usaha kepada calon suksesor atau kepada orang terdekat dari calon suksesor;

b. Terkait dengan upaya meminimalisir perbedaan knowledge, hal yang dapat dilakukan adalah pemilik/pendiri dapat memberikan pengalaman seputar rumah makan kepada penerus/calon suksesor sedini mungkin (chilhood experience).

2. Pola usaha keluarga yang dapat dilakukan oleh suksesor kepada karyawan usaha
RM. Simpang Raya Padang adalah sebagai berikut:

a. Melakukan pendekatan dan pengarahan dengan karyawan. Setelah suksesor mendapatkan ilmu dan pengalaman dari pemilik/pendiri/ pengelola sebelumnya, diharapkan suksesor juga dapat membagikannya kepada karyawan. Sehingga terciptanya kesamaan/kesetaraan pola pikir antara satu sama lain;

b. Membuat dan menerapkan Standar Operasional (SOP)

Suksesor diharapkan dapat membuat dan menerapkan SOP semua pekerjaan seputar. Hal ini dilakukan agar di kemudian saat terjadinya pemindahan tongkat estafet pada generasi penerus, dokumen tersebut dapat dijadikan sebagai acuan dalam menjalankan usaha rumah makan.

Apabila pola usha tersebut terealisasi, diharapkan pengelola dapat mengembalikan nama baik RM. Simpang Raya Padang seperti saat masa kejayaannya. Disamping itu dengan adanya penelitian ini diharapkan dapat menjadi acuan oleh para praktisi, khususnya pengelola usaha rumah makan, agar ia 
Journal of Management $\quad$ Vol. 17, No.2,2020:196-214

senantiasa menjaga usaha ini dengan baik dan mampu meneruskan pada generasi berikutnya.

Penelitian ini memiliki keterbatasan pada substansi penelitian yang hanya membahas mengenai beberapa faktor intenal yang mempengaruhi suksesi usaha rumah makan. Selain itu, penelitian ini hanya fokus pada dua konstruk penelitian (orientasi dan knowledge) itu saja. Sehingga hasil dari penelitian ini sangat di khususkan untuk internal rumah makan dan sudut pandang yang digunakan hanya terdiri dari segelintir orang dari internal, supplier dan konsumen rumah makan. Namun dengan adanya keterbatasan ini dapat dijadikan sebagai pembelajaran terhadap pelaku bisnis usaha keluarga (usaha rumah makan) lainnya.

Selanjutnya, keterbatasan juga terdapat dalam hal metodologi penelitian yang lebih mengedepankan pembahasan dengan menggunakan metode kualitatif pada satu studi kasus saja. Hal itulah yang menjadikan hasil penelitian ini belum dapat digeneralisasi pada objek penelitian lainnya/suksesi usaha keluarga lain. Keterbatasan metodologi ini juga menjadi peluang bagi peneliti selanjutnya untuk menggunakan metodologi lain yang dapat menggeneralisasi penelitian terkait topik ini. 


\section{DAFTAR PUSTAKA}

Akhavan, P., Rahimi, A., \& Mehralian, G. (2013). Developing a model for knowledge sharing in research centers. Vine, 43(3), 357-393. https://doi.org/10.1108/VINE-06-2012-0020

Alleyne, P., Indies, W., \& Pierce, A. (2015). Family business succession among Entrepreneurs: Evidence from prominent family businesses in Barbados. (September).

Arthadian, R., Retno, R. R., Bisnis, P. M., Manajemen, P. S., Petra, U. K., \& Siwalankerto, J. (2014). Keterlibatan Anggota Keluarga Dalam Family Business dan Hubungannya Terhadap Kinerja Bisnis ( Studi Pada Perusahaan Sektor Makanan dan Minuman di Sidoarjo). Agora, 2(2).

Bierwerth, M., Schwens, C., Isidor, R., \& Kabst, R. (2015). Corporate entrepreneurship and performance: A meta-analysis. Small Business Economics, 45(2), 255-278. https://doi.org/10.1007/s11187-015-9629-1

Budiman, R., \& Mustamu, R. (2014). Bidang Distribusi Makanan. 2(2).

Burhan, B. (2013). Metode Penelitian Kualitatif. Jakarta: Raja Grafindo Persada.

Chirico, F. (2008). Knowledge accumulation in family firms: Evidence from four case studies. International Small Business Journal, 26(4), 433-462. https://doi.org/10.1177/0266242608091173

Cong, C., Dempsey, M., \& Xie, H. M. (2017). Political skill, entrepreneurial orientation and organizational justice: A study of entrepreneurial enterprise in China. International Journal of Entrepreneurial Behaviour and Research, 23(1), 20-34. https://doi.org/10.1108/IJEBR-052015-0103

Cresswell, J. W. (2013). Qualitative Inquiry \& Research Design (Third). London: SAGE Publcations.

Elenurm, T. (2012). Entrepreneurial orientations of business students and entrepreneurs. Baltic Journal of Management, 7(2), 217-231. https://doi.org/10.1108/17465261211219822

Ibrahim. (2015). Metodologi Penelitian Kualitatif (E. Kurnanto, ed.). Bandung: ALFABETA.

Islam, M. Z., Jasimuddin, S. M., \& Hasan, I. (2015). Organizational culture, structure, technology infrastructure and knowledge sharing. Vine, 45(1), 67-88. https://doi.org/10.1108/vine-052014-0037

Khvatova, T., Block, M., Zhukov, D., \& Lesko, S. (2016). How to measure trust: the percolation model applied to intra-organisational knowledge sharing networks. Journal of Knowledge Management, 20(5), 918-935. https://doi.org/10.1108/JKM-11-2015-0464

Kuratko, D. F. (2010). “Corporate entrepreneurship: an introduction and research review” (2nd ed.). New York.

Kusuma, G. H. (2014). Transfer Pengetahuan antar Generasi pada Perusahaan Keluarga Gabriella Hanny Kusuma. 4-6.

Kusuma, G. H. (2016). Metode Transfer Pengetahuan Pada Perusahaan Keluarga Di Indonesia. Modus. 27(2), 125. https://doi.org/10.24002/modus.v27i2.552

Lesal, P. R. (2015). Analisa Transformasi Nilai Dalam Proses Suksesi Pada Pt. Prima Jaya Di Surabaya. Agora, 3(2), 158-166. 
Lin, H. F. (2015). Linking knowledge management orientation to balanced scorecard outcomes. Journal of Knowledge Management, 19(6), 1224-1249. https://doi.org/10.1108/JKM-04-20150132

Patel, P. C., \& Fiet, J. O. (2011). Knowledge combination and the potential advantages of family firms in searching for opportunities. Entrepreneurship: Theory and Practice, 35(6), 1179-1197. https://doi.org/10.1111/j.1540-6520.2011.00497.x

Prasetio, Y., \& Nugraheni, R. (2018). Transfer Pengetahuan Pada Perusahaan Keluarga ( Studi pada Perusahaan Keluarga Arya Mas ). 7, 1-11.

Short, J. C., Sharma, P., Lumpkin, G. T., \& Pearson, A. W. (2016). Oh, the Places We'll Go! Reviewing Past, Present, and Future Possibilities in Family Business Research. Family Business Review, 29(1), 11-16. https://doi.org/10.1177/0894486515622294

Shu, C., De Clercq, D., Zhou, Y., \& Liu, C. (2019). Government institutional support, entrepreneurial orientation, strategic renewal, and firm performance in transitional China. International Journal of Entrepreneurial Behaviour and Research, 25(3), 433-456. https://doi.org/10.1108/IJEBR07-2018-0465

Shu, X. (2013). Firm Performance, Entrepreneurship and Business Succession in Family Firms.

Suess-Reyes, J. (2017). Understanding the transgenerational orientation of family businesses: the role of family governance and business family identity. Journal of Business Economics, 87(6), 749777. https://doi.org/10.1007/s11573-016-0835-3

Susanto, A. ., \& Susanto, P. (2013). The Dragon Network: Inside Stories of Most Successful Chinese Family Business. John Wiley \& Sons.

Tangradi, D. (2016). Tahapan Perencanaan Suksesi Pada. 4(2).

Vij, S., \& Farooq, R. (2014). Knowledge Sharing Orientation and Its Relationship with Business Performance: A Structural Equation Modeling Approach. IUP Journal of Knowledge Management, 12(3), 17-41. https://doi.org/10.4018/ijkm.2014070103

Wales, W. J. (2016). Entrepreneurial orientation: A review and synthesis of promising research directions. International Small Business Journal: Researching Entrepreneurship, 34(1), 3-15. https://doi.org/10.1177/0266242615613840

Warnar, P. (2012). Master Thesis Family businesses and knowledge transfer. (1286781).

Woodfield, P. J., Shepherd, D., \& Woods, C. (2017). How can family winegrowing businesses be sustained across generations? International Journal of Wine Business Research, 29(2), 122139. https://doi.org/10.1108/IJWBR-12-2015-0052 